\title{
Kinetics and cellular localisation of putrescine uptake in human lung tissue
}

\author{
P H M Hoet, D Dinsdale, C P L Lewis, E K Verbeken, J M Lauweryns, B Nemery
}

\begin{abstract}
Background-The polyamines (putrescine, spermidine, and spermine) are involved in cellular growth, proliferation, and differentiation. In the lungs of various species, polyamines are accumulated by an active uptake system which also mediates the uptake of cystamine and paraquat. In the rat lung putrescine uptake has been shown to be cellspecific, occurring predominantly in the alveolar epithelium. The aim of this study was to characterise the uptake of putrescine in human lung.
\end{abstract}

Methods-Lung tissue was obtained from 31 patients undergoing surgery for lung cancer. Slices $(0.7 \mathrm{~mm}$ thick) from nontumour containing lung parenchyma were incubated for 15-60 minutes in Krebs-Ringer phosphate buffer with various concentrations of putrescine (2.5 to $80 \mu \mathrm{mol} / 1)$ containing $0.1 \mu \mathrm{Ci}$ $\left[1,4-{ }^{14} \mathrm{C}\right]$-putrescine. Uptake was assessed from tissue radioactivity. For autoradiographic imaging, slices were incubated for 30 minutes with $2.5 \mu \mathrm{mol} / /$ putrescine containing $2.5 \mathrm{mCi}\left[1,4 \mathrm{n}-{ }^{3} \mathrm{H}\right]$-putrescine. Results-The accumulation of $\left[{ }^{14} \mathrm{C}\right]-$ putrescine into slices was time-dependent and energy-dependent, and obeyed saturation kinetics, with mean calculated values for $V_{\max }$ (maximal rate of uptake) of $414 \mathrm{nmol} / \mathrm{g} / \mathrm{hour}$ and for $\mathrm{K}_{\mathrm{m}}$ (medium concentration at which the rate of uptake is half $V_{\max }$ ) of $7 \cdot 2 \mu \mathrm{mol} / 1$, with a large interindividual variation. Competitive inhibition was observed on incubation with cystamine, which appears to have a high affinity for the uptake system since its calculated $K_{i}$ (concentration of inhibitor at which the $K_{m}$ is doubled) was $3.2 \mu \mathrm{mol} / 1$. Ultrastructural autoradiography showed labelling over both type I and type II cells of the alveolar epithelium, but not over the endothelium or any cells of the interstitium. Alveolar macrophages were also devoid of label.

Conclusions-These results show that the human lung possesses an active uptake system for putrescine, and probably also cystamine, which is located in both cell types of the alveolar epithelium. These findings may be used to develop tests for the assessment of the alveolar epithelium.

(Thorax 1993;48:1235-1241)
Putrescine, or 1,4-diaminobutane $\mathrm{NH}_{2}-$ $\left.\left(\mathrm{CH}_{2}\right)_{4}-\mathrm{NH}_{2}\right)$, is an endogenous diamine resulting from the decarboxylation of ornithine by the ubiquitous and highly inducible enzyme ornithine decarboxylase. Putrescine is the precursor for the biosynthesis of the other polyamines, spermidine and spermine. The polyamines are organic cations involved in, and essential for, many cellular processes including cell growth, proliferation, and differentiation in both normal and malignant cells. ${ }^{12}$

Interest in the handling of polyamines by the lung has stemmed in part from the observation that the pneumotoxic herbicide paraquat is accumulated by the lung (and not by other major organs) in a saturable and energy-dependent manner via an active uptake system. ${ }^{3}$ It has also been shown that the polyamines putrescine, spermidine and spermine, ${ }^{45}$ as well as the physiologically occurring disulphide cystamine, ${ }^{6}$ are excellent natural substrates for the uptake system.

In vitro and in vivo experiments have demonstrated the existence of a polyamine uptake system in the lungs of all laboratory animal species examined, ${ }^{47}$ and BrookeTaylor $e t a l^{8}$ have indicated, in limited experiments, that a similar mechanism for the accumulation of polyamines and paraquat also exists in human peripheral lung. In the rat the accumulation of polyamines has been shown to be cell-specific, occurring predominantly in alveolar type II cells, ${ }^{9-12}$ alveolar type I cells ${ }^{11}$ and, at least in vitro, also in Clara cells. ${ }^{9-11}$ The purpose of the present study was to investigate more fully the polyamine uptake in the human lung and to define (1) the kinetic parameters for the accumulation of putrescine; (2) the competitive inhibition of putrescine uptake by cystamine; and (3) the cell types into which putrescine is accumulated.

\section{Methods}

REAGENTS

$\left[1,4-{ }^{14} \mathrm{C}\right]$-Putrescine dihydrochloride (110 $\mathrm{mCi} / \mathrm{mmol}), \quad\left[1,4 \mathrm{n}-{ }^{3} \mathrm{H}\right]$-putrescine dihydrochloride $(24 \mathrm{Ci} / \mathrm{mmol}), \quad \mathrm{L}-\left[4,5-{ }^{3} \mathrm{H}\right]$-leucine $(140 \mathrm{Ci} / \mathrm{mmol})$ and $\mathrm{D}-\left[6-{ }^{14} \mathrm{C}\right]$-glucose $(55 \cdot 7$ $\mathrm{mCi} / \mathrm{mmol}$ ) were purchased from Amersham International Ltd (Brussels, Belgium). Soluene 350 tissue solubiliser, Emulsifier Safe and Ultima Gold scintillants and plastic scintillation vials $(20 \mathrm{ml}$ and $5 \mathrm{ml})$ were purchased from Packard NV (Zellik, Belgium). Putrescine dihydrochloride, cystamine

Received 26 March

22 July 1993

Revised version received

11 August 1993

Accepted 12 August 1993 
dihydrochloride, and antimycin A were purchased from Sigma (Deisenhofen, Germany).

\section{PREPARATION AND INCUBATION OF LUNG}

TISSUE

Lung tissue was obtained from 31 patients (three women aged 59, 64, and 74 years, and 28 men aged 36 to 76 years) undergoing lobectomy or pneumectomy, mostly for lung cancer. Within minutes after resection a large portion of macroscopically non-tumour containing tissue was cut from the surgical specimen, the pleura was removed, and the tissue was placed in Krebs-Ringer phosphate buffer (KRPB) containing $\mathrm{NaCl}(130 \mathrm{mmol} / \mathrm{l}), \mathrm{KCl}$ (5.4 mmol/l), $\mathrm{CaCl}_{2}(1.9 \mathrm{mmol} / \mathrm{l}), \mathrm{MgSO}_{4}$ (1.29 $\mathrm{mmol} / \mathrm{l}), \quad \mathrm{Na}_{2} \mathrm{HPO}_{4}(10 \mathrm{mmol} / \mathrm{l})$, glucose $(11 \mathrm{mmol} / \mathrm{l})(\mathrm{pH} 7 \cdot 4)$ at room temperature.

Within one hour slices of lung parenchyma (without visible bronchi) of $0.7 \mathrm{~mm}$ thickness and cut surfaces of about $0.5 \mathrm{~cm}^{2}$ were prepared with a McIlwain tissue chopper (Mickle Laboratories, Surrey, UK). The slices were weighed and incubated in lots of approximately $30 \mathrm{mg}$ in $3 \mathrm{ml} \mathrm{KRPB}$ in $40 \mathrm{ml}$ polyethylene flasks placed in a shaking water bath (120-140 strokes $/ \mathrm{min})$ at $37^{\circ} \mathrm{C}$ or $4^{\circ} \mathrm{C}$. Putrescine uptake was determined by the method of Smith et al. ${ }^{7}$ The slices were incubated for various lengths of time $(15,30,45$, and 60 minutes) with various concentrations of putrescine $(2.5$ to $80 \mu \mathrm{mol} / \mathrm{l})$ containing $\left[1,4-{ }^{14} \mathrm{C}\right]$-putrescine $(0 \cdot 1 \mu \mathrm{Ci}$ per incubation flask), with or without other added compounds (cystamine, antimycin $\mathrm{A}$ ), as indicated in the results.

At the end of the incubation the slices were removed, briefly immersed in KRPB, blotted, weighed, and dissolved in Soluene 350, whereafter $10 \mathrm{ml}$ of Ultima Gold scintillant was added. In addition, a $0.1 \mathrm{ml}$ aliquot of medium was added to $0.4 \mathrm{ml}$ water and 4.5 ml Emulsifier Safe scintillant. The tissue and medium radioactivity were determined by liquid scintillation spectrometry using a Beckman ls5000ce counter fitted with appropriate quench correction curves to convert counts per minute to disintegrations per minute (dpm). The accumulation of putrescine (nmol/g/hour) was derived from the tissue associated radioactivity, the specific activity, the wet weight after incubation, and the incubation time.

In some instances protein synthesis, glucose metabolism, and putrescine uptake were assessed in the incubated lung slices within one hour of resection or after keeping the tissue, before slicing and incubation, for two or three hours in KRPB. Protein synthesis was determined as the stable incorporation of radioactivity into acid precipitable material after 30 minutes incubation with $\left[{ }^{3} \mathrm{H}\right]$-leucine $(0.07 \mu \mathrm{Ci} / \mathrm{ml}) .^{13}$ Glucose metabolism was quantified by trapping radioactive $\mathrm{CO}_{2}$ in $\mathrm{NaOH}$ during incubation with $\left[6-{ }^{14} \mathrm{C}\right]-$ glucose $(0.4 \mu \mathrm{Ci} / \mathrm{ml}) .{ }^{14}{ }^{15}$ in $\mathrm{KRPB}$ containing $2.5 \mu \mathrm{mol} / 1$ putrescine and $\left[1,4 n-{ }^{3} \mathrm{H}\right]$-putrescine $(500 \mu \mathrm{Ci} / \mu \mathrm{mol})$. At the end of the incubation the slices were fixed in $6.5 \%$ glutaraldehyde in $0.1 \%$ cacodylate buffer ( $\mathrm{pH} 7 \cdot 4$ ) and prepared for autoradiography as previously described..$^{911}$ Slices for light microscopy were embedded in EPON 812 resin and sections of $1 \mu \mathrm{m}$ thickness were mounted onto microscope slides. The slides were dipped at $40^{\circ} \mathrm{C}$ into an Ilford Nuclear Research Emulsion Gel K2 nuclear emulsion $(25 \%)$, dried, and kept at $4^{\circ} \mathrm{C}$ in the dark. After 50 days the slides were developed (Ilford Phenisol, 15 minutes), fixed (1\% acetic acid, two minutes, $30 \%$ sodium thiosulphate) and stained $(0 \cdot 1 \%$ toluidine blue in $0.1 \%$ borax, $37^{\circ} \mathrm{C}$, nine minutes). Slices for electron microscopy were postfixed in $1 \%$ osmium tetroxide in buffer $(0.1 \mathrm{~mol} / 1$ with respect to sodium cacodylate and $0.04 \mathrm{~mol} / \mathrm{l}$ with respect to potassium ferrocyanide) for three hours and stained en bloc in $2 \%$ uranyl acetate at $60^{\circ} \mathrm{C}$ for 16 hours. They were embedded in Araldite and sections, $1 \mu \mathrm{m}$ thick, were examined by light microscopy. Further $1 \mu \mathrm{m}$ sections were cut from selected areas, collected on celloidin-coated microscope slides, and coated with Ilford Nuclear Research Emulsion Gel L4 emulsion. They were exposed for 21 days in a light proof desiccator at $4^{\circ} \mathrm{C}$ before the emulsion was developed (Kodak D-19, four minutes). The unstained sections were transferred to grids and examined, by electron spectroscopic imaging, in a Zeiss CEM 902A electron microscope.

\section{CALCULATION OF THE KINETIC PARAMETERS} AND STATISTICAL ANALYSES

When duplicate determinations were available the average value was taken. The apparent kinetic parameters, $V_{\max }$ (the maximal rate of uptake expressed in $\mathrm{nmol} / \mathrm{g} /$ hour ) and $\mathrm{K}_{\mathrm{m}}$ (the medium concentration at which the rate of uptake is half $V_{\max }$, expressed in $\mu \mathrm{mol} / 1$ substrate), were calculated from a HanesWoolf plot. ${ }^{16}$

For incubations in the presence of cystamine, competitive inhibition was verified by a Cornish-Bowden plot $^{17}$ and the inhibitor constant $\mathrm{K}_{\mathrm{i}}$ (the concentration of the inhibitor at which the $K_{m}$ is doubled, of expressed in $\mu \mathrm{mol} / 1$ inhibitor) was determined using the method of Lineweaver-Burk. ${ }^{16}$

Because of the large variation between different patients a box plot $^{18}$ was used to detect outlying values. This method using the median, the approximate quartiles (upper and lower hinge), and $\mathrm{H}$ spread (difference between upper and lower hinge) allowed the identification of outlying values at each incubation: data points falling outside the range covered by the lower hinge minus 1.5 times the $\mathrm{H}$ spread and the upper hinge plus 1.5 times the $\mathrm{H}$ spread were considered as outlying values. ${ }^{18}$

Data from control and treated slices were compared by the Student's $t$ test for paired data, or by analysis of variance with Duncan grouping using the SAS/STAT (SAS Institute 
Figure 1 Linearity with time of putrescine accumulation by human lung slices. Slices from four patients were incubated at $37^{\circ} \mathrm{C}$ or $4^{\circ} \mathrm{C}$ with $10 \mu \mathrm{mol} / \mathrm{l}(\nabla--\nabla)$ or $80 \mu \mathrm{mol} / \mathrm{l}(\triangle-\triangle)$ $\left[{ }^{4} \mathrm{C}\right]$-putrescine. Data are mean $(S D)(n=4)$ after subtraction of the values obtained at $4^{\circ} \mathrm{C}$.

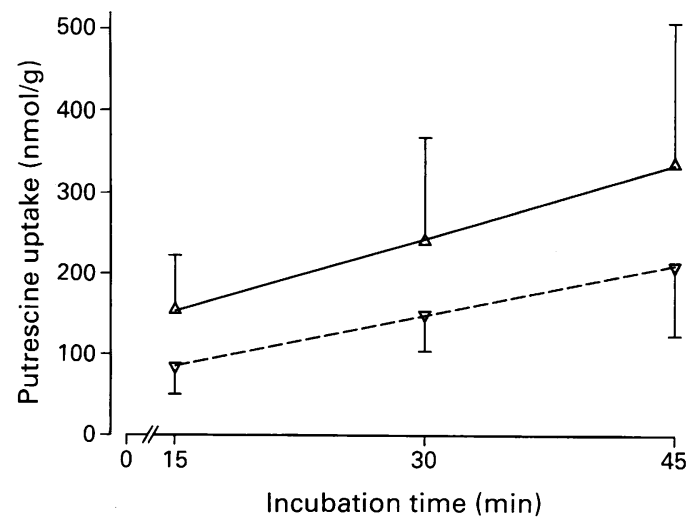

Inc., Cary, North Carolina, USA) package (sixth version). The level of significance was set at $\mathrm{p}<0.05$.

\section{Results}

PRELIMINARY EXPERIMENTS (VIABILITY OF LUNG TISSUE)

Preliminary experiments were carried out in a room adjoining the operating theatre to ensure that slices could be prepared and used some time after the lung tissue had been removed. The uptake of putrescine was compared in lung slices prepared immediately upon receipt of the tissue and in slices prepared from such tissue kept for one hour at room temperature in KRPB. The results from four patients showed no significant differences in the rate of uptake of putrescine between fresh and one hour old tissue (data not shown). Subsequent data were all obtained with tissue which was transported in KRPB at room temperature and reached the laboratory well within one hour of the resection.

Measurements of the incorporation of $\left[{ }^{3} \mathrm{H}\right]$-leucine into proteins, the oxidation of $\left[6-{ }^{14} \mathrm{C}\right]$-glucose, or the uptake of putrescine in tissue from four patients showed no differences between incubations started approximately one hour after resection and those carried out after keeping the tissue for another two or three hours in KRPB at room temperature, thus indicating that the metabolic functions of the lung tissue were well preserved over this time (data not shown).

\section{TIME-DEPENDENT AND ENERGY-DEPENDENT} UPTAKE OF PUTRESCINE

The accumulation of putrescine (10 and $80 \mu \mathrm{mol} / \mathrm{l}$ ) into human lung slices was found to be linear with time up to 45 minutes of incubation (fig 1). Uptake in medium containing $80 \mu \mathrm{mol} / \mathrm{l}$ putrescine reached a plateau after incubation for one hour (data not shown). In all subsequent experiments the duration of incubation for uptake experiments was 30 minutes (except in one subject where it was 45 minutes). Tissue accumulation during cold $\left(4^{\circ} \mathrm{C}\right)$ incubation was found to be much less than at $37^{\circ} \mathrm{C}$, and to be linear with both time (data not shown) and concentration (fig 2). The incorporation of antimycin A $(0.4 \mu \mathrm{g} / \mathrm{ml})$ into medium containing 10 or $80 \mu \mathrm{mol} / 1$ putrescine significantly reduced the mean (SD) uptake to $28 \%(17 \%)$ and $27 \%(8 \%)$ of the control levels respectively $(n=5)$.

\section{UPTAKE OF PUTRESCINE}

The data for the uptake of putrescine in 31 subjects are summarised in fig 2 . Of a total of
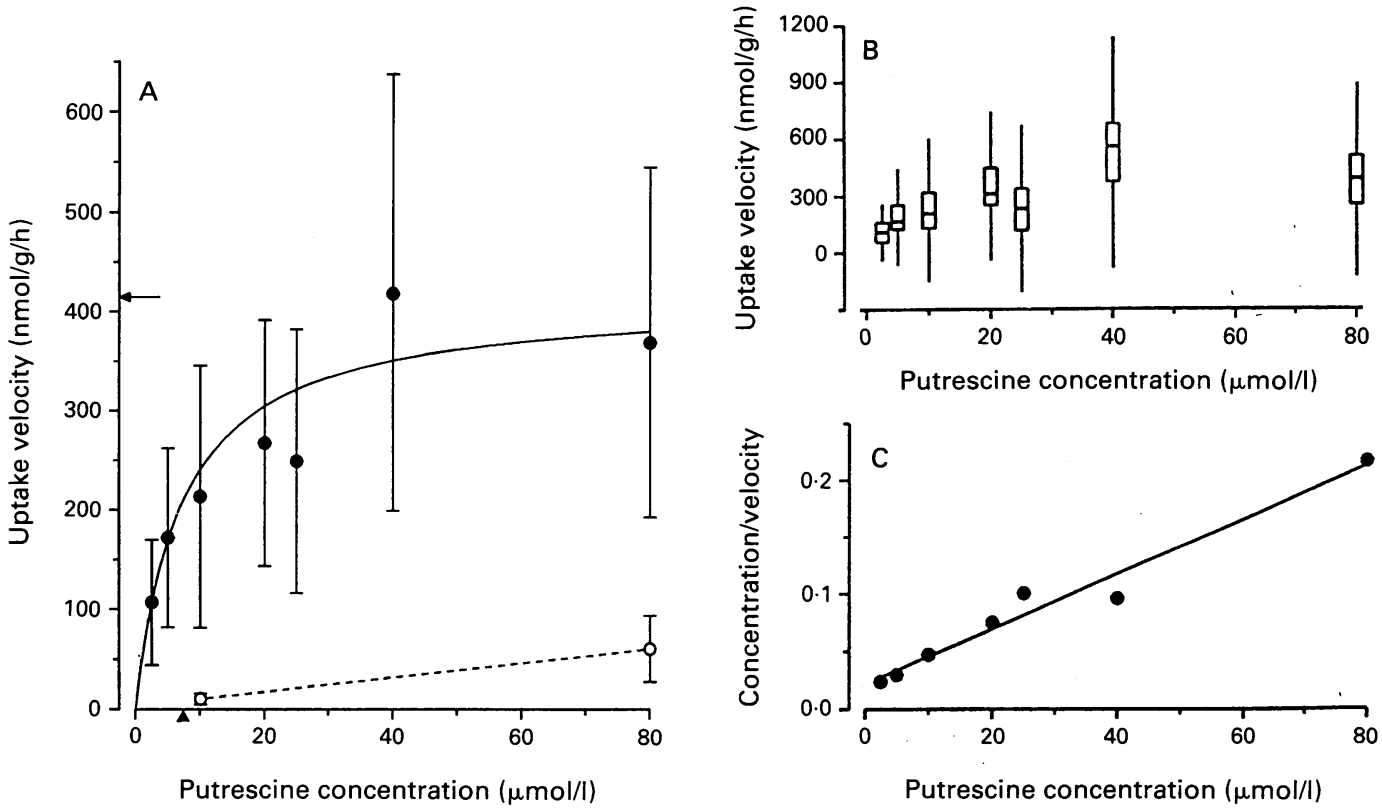

Figure 2 Accumulation of putrescine by lung slices from 31 subjects. Slices were incubated for 30 minutes at $37^{\circ} \mathrm{C}$ or $4^{\circ} \mathrm{C}$ in medium containing various concentrations of putrescine and $0 \cdot 1 \mu \mathrm{Ci}\left[1,4-{ }^{14} \mathrm{C}\right]$-putrescine per incubation. Values obtained at $4^{\circ} \mathrm{C}$ were subtracted from those obtained at $37^{\circ} \mathrm{C}$. (a) Unweighted means of the data. The curve is the Michaelis-Menten hyperbola defined by the kinetic parameters $K_{m}(\boldsymbol{\Delta})$ and $V_{\max }(\leftarrow)$ given below $(c)$. Symbols represent mean $(S D)$ putrescine uptake at $4^{\circ} \mathrm{C}(\mathrm{O})$ or $37^{\circ} \mathrm{C}(\mathrm{O})$. (b) Data are presented as a box plot enclosing the median (-) and the upper and lower hinges, with bars indicating the "acceptable spread of the data" (14-58 measurements per concentration). (c) Hanes-Woolf plot of the (unweighted) means of the data. The linear regression (correlation coefficient $r=0.93, n=7, p=0.0004$ ) yields values for $K_{m}$ of $7.2 \mu$ mol/l and $V_{\max }$ of 414 nmol/g/hour. 

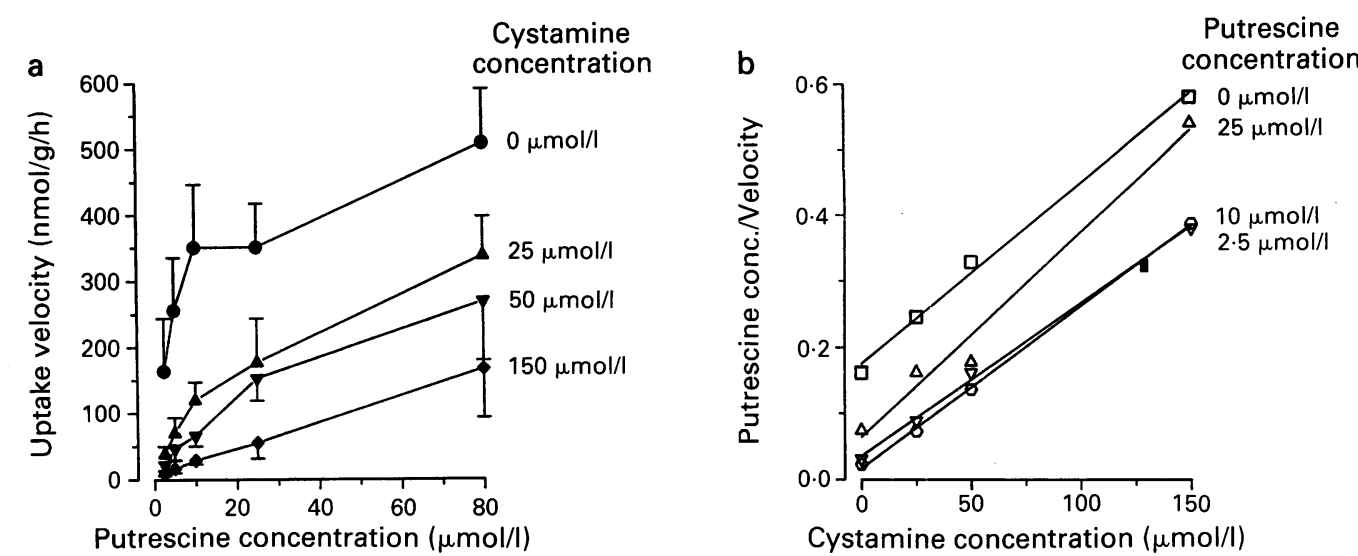

Figure 3 Competitive inhibition of putrescine accumulation in human lung slices by cystamine. Slices from six patients were incubated for 30 minutes at $37^{\circ} \mathrm{C}$ or $4^{\circ} \mathrm{C}$ in medium containing various concentrations of $\left[{ }^{4} \mathrm{C}\right]$-putrescine, with various concentrations of cystamine $(0,25,50,150 \mu \mathrm{mol} / \mathrm{l})$. Values obtained at $4^{\circ} \mathrm{C}$ were subtracted from those obtained at $37^{\circ} \mathrm{C}$. (a) Data are mean (SD). (b) Cornish-Bowden plot of the mean values. The slope of the linear regression lines (correlation coefficients $r>0.99)$ do not differ $(p>0.5)$, whereas the intercepts do $(p<0.0001)$. Data for putrescine concentration $5 \mu$ molll coincide with those of 10 and $2.5 \mu \mathrm{moll}$ and, for clarity, are not shown.

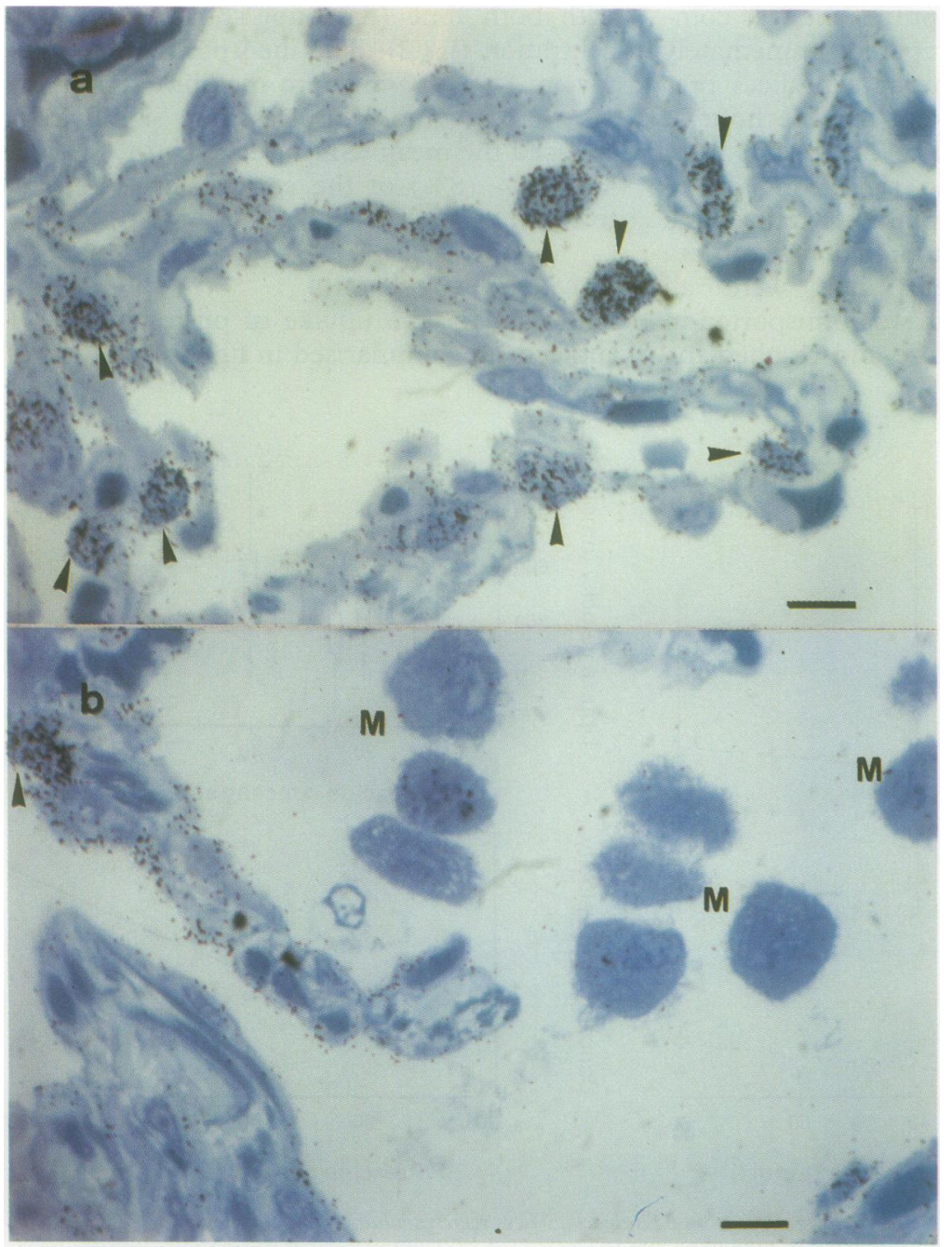

Figure 4 Autoradiographs of human lung tissue incubated with 2.5 Mmoll $\left[{ }^{3} \mathrm{H}\right]-$ putrescine for 30 minutes. Resin sections, $1 \mu$ m thick, were stained with toluidine blue and examined by light microscopy. The labelling is mainly found over type II cells (arrowheads) and along the air side of alveoli, suggesting that type I cells are also labelled. Little or no labelling is found in other structures such as blood vessels, erythrocytes, or alveolar macrophages (M). Bar $=10 \mu \mathrm{m}$.
318 observations, only 10 were considered to $\vec{N}$ be outlying values (see methods), ${ }^{18}$ and they were not used in the subsequent calculations. 을 The accumulation found on incubation at $4^{\circ} \mathrm{C}$ was considered to represent passive diffusion and this was used to calculate the $\varnothing_{\varnothing}$ effective (active) uptake by subtracting the $\overline{3}$ values found at $4^{\circ} \mathrm{C}$ from those obtained at $\stackrel{\mathbb{D}}{-}$ $37^{\circ} \mathrm{C}$. For unknown reasons (possibly varia- $\vec{\oplus}$ tions in the cellular composition of the slices) a relatively large intra-individual variation in uptake was occasionally observed. This ren- o dered the calculation of kinetic parameters of uptake for each individual difficult and, in some cases, invalid. The kinetic parameters were therefore computed from the overall means of the uptake at each concentration. This gave a mean $\mathrm{K}_{\mathrm{m}}$ of $7 \cdot 2 \mu \mathrm{mol} / 1$ and a mean $V_{\max }$ of $414 \mathrm{nmol} / \mathrm{g} / \mathrm{hour}$. In order to have some information on the spread of these values these parameters were also calculated using the values of the upper and lower hinges of the data. This resulted in $\mathrm{K}_{\mathrm{m}}$ values of 7.2 and $6.3 \mu \mathrm{mol} / 1$ and $V_{\max }$ values of 560 and $266 \mathrm{nmol} / \mathrm{g} /$ hour, respectively.

COMPETITIVE INHIBITION BY CYSTAMINE

The accumulation of putrescine was $D$ decreased in the presence of cystamine, with the degree of inhibition being dependent on $N$ the cystamine concentration (fig 3a). A Cornish-Bowden plot showed that the apparent $\mathrm{K}_{\mathrm{m}}$ for the uptake of putrescine increased $\omega$ with the cystamine concentration, whereas $\mathrm{V}_{\max }$ remained unchanged, thus indicating that the inhibition by cystamine was competitive (fig $3 b$ ). The inhibitor constant $\mathrm{K}_{i}$ was calculated to be $3 \cdot 2 \mu \mathrm{mol} / 1$ cystamine.

\section{AUTORADIOGRAPHY}

Distinct labelling with silver grains was observed by light microscopy over many cuboidal cells in the niches of the alveoli $\frac{\delta}{0}$ (fig 4a). The interstitium of the alveolar septa and also the macrophages lying within the $\frac{0}{7}$ airspaces were largely devoid of these grains (fig 4b). Autoradiographs of resin sections, cut perpendicular to the lung slices, showed 


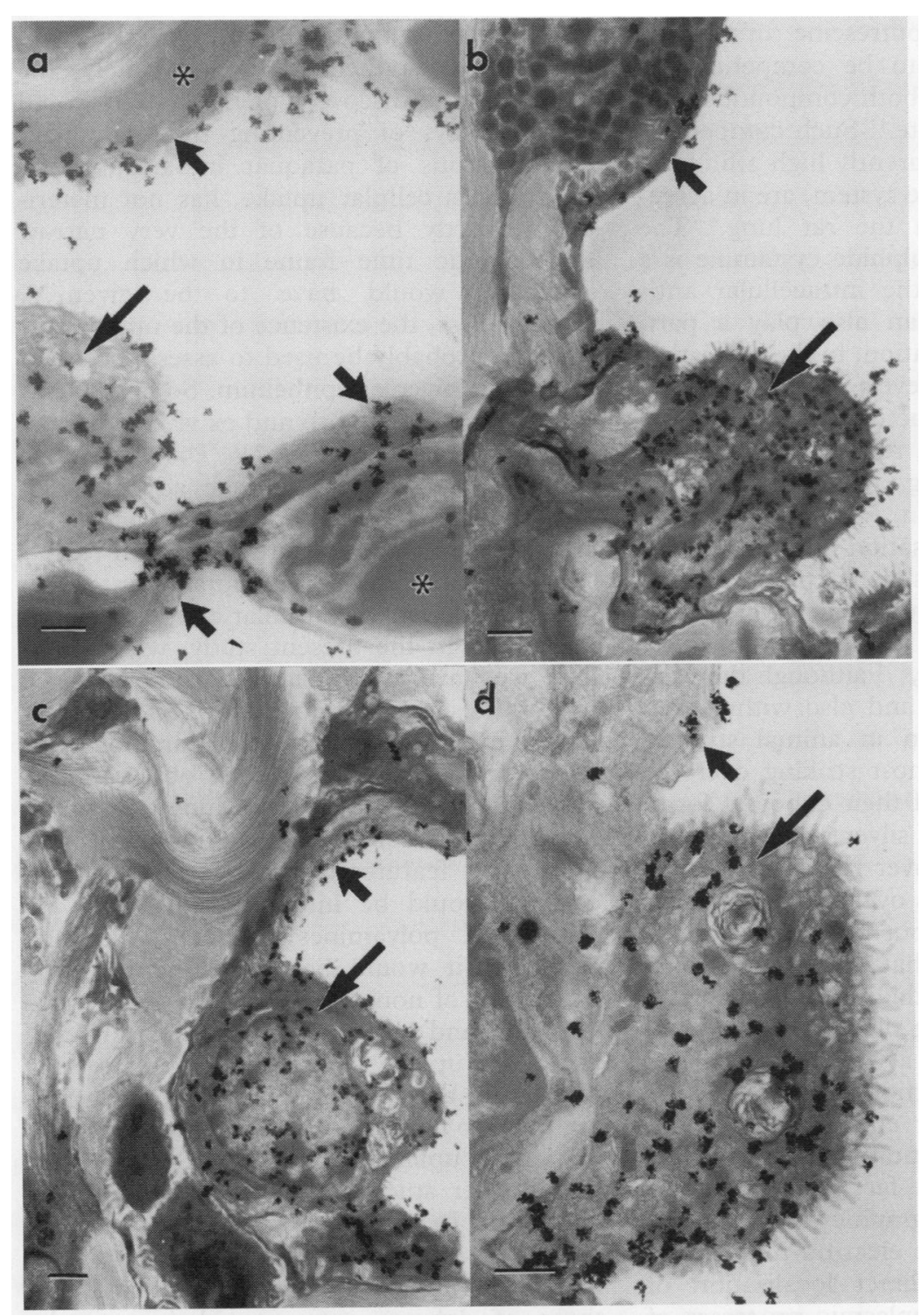

Figure 5 Autoradiographs of human lung tissue incubated with $2 \cdot 5 \mu$ molll

$\beta H]-p u t r e s c i n e$ for 30 minutes. Unstained resin sections, $1 \mu \mathrm{m}$ thick, were examined by electron spectroscopic imaging. Silver grains are evident over the type II pneumocytes long arrows) and the lining of the alveoli (short arrows), but not over erythrocytes (*) or the paranuclear regions of the endothelium. Cellular and non-cellular components of the paranuclear regions of the endothelium. Cellular and non-cellular components of the distributed over both the nucleus and cytoplasm of the type II cells. Bars $=1 \mu \mathrm{m}$.

uniform intensity of labelling throughout the thickness of each slice, indicating that there was no hindrance to the diffusion of putrescine and no viability problems within the tissue. The heavily labelled cuboidal alveolar cells were identified by electron microscopy as type II pneumocytes (fig 5a). Silver grains were also observed over the nuclei of type I pneumocytes and the lining of the alveolus. The resolution of the autoradiography technique is insufficient to discriminate between labelling of the thin profiles of cytoplasmic processes from type I pneumocytes and those of endothelial cells. Silver grains were, however, rarely observed over the paranuclear regions of endothelial cells. Erythrocytes and leucocytes, within the capillaries, were also unlabelled. Fibroblasts, monocytes and granulocytes of the alveolar interstitium were largely devoid of silver grains (fig 5b). Very few silver grains were found over the elastin, collagen, or other non- cellular components of the interstitium (fig 5c). Detailed examination of the type II pneumocytes indicated uniform distribution of label throughout both the nucleus and cytoplasm of these cells (fig $5 \mathrm{~d}$ ). In general, there were no ultrastructural signs of cellular damage in any particular cell population.

\section{Discussion}

Our experiments confirm that the human lung possesses an active uptake system for putrescine, with characteristics which are very similar to those found in the rat, both with regard to biochemical parameters and the cellular specificity for the alveolar epithelium.

The results of our preliminary experiments indicated that the putrescine uptake system, as well as protein synthesis and glucose oxidation, remained stable for at least three hours after collection of the lung tissue, thus demonstrating that tissue slices are appropriate for the short term study of pulmonary metabolism. ${ }^{19}$ Nevertheless, there was considerable variation in the data from different patients-for example, in the one hour old tissue examined at the hospital individual values for $\mathrm{K}_{\mathrm{m}}$ varied from 4.6 to $59.5 \mu \mathrm{mol} / 1$ and $V_{\max }$ varied from 413 to $794 \mathrm{nmol} / \mathrm{g} /$ hour in the four patients investigated. In the entire patient population examined we found no correlation between the individual kinetic parameters and the age of the patients; however, the age range in our series of patients with lung cancer was not large, since most subjects $(71 \%)$ were aged between 50 and 70 years, usually being men (90\%) and smokers or former smokers. We grouped the patients into subjects with histologically "normal" alveolar parenchyma $(n=23)$, subjects with signs of emphysema $(n=5)$, and subjects with signs of fibrosis $(n=3)$, but found no consistent differences between these three groups, and the normal tissue did not appear to be less variable. We did not find an effect of gender, but there were only three women, and no differences were seen between the different categories of patients based on tumour type.

Our parameters of putrescine uptake in the human lung (apparent $\mathrm{K}_{\mathrm{m}}$ of $7 \cdot 2 \mu \mathrm{mol} / \mathrm{l}$ and $\mathrm{V}_{\max }$ of $414 \mathrm{nmol} / \mathrm{g} / \mathrm{hour}$ ) are similar to the values found previously in lung slices from the rat $\left(K_{m} 7 \mu \mathrm{mol} / 1, V_{\max } 330 \mathrm{nmol} / \mathrm{g} /\right.$ hour $^{20}$ $\mathrm{K}_{\mathrm{m}} 19 \cdot 8-30.6 \mu \mathrm{mol} / \mathrm{l}, \mathrm{V}_{\max }$ 696-972 nmol/ $\mathrm{g} /$ hour $\left.^{9}\right)$ and the hamster $\left(\mathrm{K}_{\mathrm{m}} 35 \mu \mathrm{mol} / \mathrm{l}, \mathrm{V}_{\max }\right.$ $769 \mathrm{nmol} / \mathrm{g} /$ hour (unpublished observations)). They are also similar to the data reported for the human lung by Brooke-Taylor et $a l^{8}$ who made their calculations in four patients using only four concentrations, all higher than $\mathrm{K}_{\mathrm{m}}$. Studies by Rannels et $a l,{ }^{5}$ and Wyatt et $a l^{10}$ have shown that polyamine and paraquat uptake are not simply artifacts of using tissue slices, since active uptake was also seen in isolated perfused rat lung. A study by Rao and Mehendale, ${ }^{21}$ also in perfused rat lung, apparently contradicts the existence of active uptake, but this can be explained by their use of only very high (millimolar) concentrations of polyamines in the perfusate. 
The inhibition of putrescine uptake by cystamine was found to be competitive in nature, suggesting that both compounds bind to a common uptake site. ${ }^{17}$ Such competitive inhibition, and the apparently high affinity of cystamine for the uptake system, are in agreement with findings in the rat lung. ${ }^{6}$ The naturally occurring disulphide cystamine is a possible precursor of the intracellular antioxidant taurine and can also play a part, through protein $S$-thiolation, in the regulation of cellular NADPH levels in response to oxidative stress. ${ }^{6}$ The active uptake of cystamine could, therefore, represent one of the strategies of the lung for increasing its defence against oxidation.

The cellular localisation of putrescine accumulation was investigated by autoradiography and this gave results which were qualitatively very similar to those previously obtained in the rat lung, ${ }^{9-11}$ although the variation between patients and also within each section was larger than in animal studies. Labelling was clearly most striking over the type II cells, because of their cuboidal form, but a similar density of silver grains per unit area was often found over type I cells. The presence of silver grains over the paranuclear region of type I cells, but not that of endothelial cells, indicated that putrescine is only accumulated by the epithelium. In our previous study ${ }^{11}$ with rat lung slices we could positively establish that the activity was localised over the epithelial portion of the alveolar septa, rather than their endothelial portion, because we used a quantitative morphometric analysis to overcome the fact that the resolution of the autoradiographic technique is insufficient - even at the electron microscope level-for a reliable, direct localisation of activity in the thin cytoplasmic processes of the type I cells. In the present study we did not undertake this time consuming morphometric analysis, but the similarity between the present and the previous findings is such that we can confidently conclude that most of the putrescine label was indeed located in type I and type II cells. The restriction of this uptake to the epithelium could not be attributed to the accessibility of the medium, as alveolar macrophages were unlabelled. The contribution of type I and type II cells to the total uptake of putrescine by lung slices is thus likely to overshadow that of any other cell type such as non-ciliated bronchiolar epithelial cells which also accumulate putrescine in rat lung slices. ${ }^{9-11}$ With regard to the latter possibility for the human lung, our sampling strategy was such that only few bronchiolar regions were available in the peripheral parenchyma used for incubations. When such areas were present, a generally low labelling was present in some bronchiolar epithelial cells only, but further experiments will be needed to specifically address this question.

What are the possible (clinical) implications of having established that the human lung possesses an active uptake system for polyamines and cystamine, which is specifi- cally located in the type I and type II cells of the alveolar epithelium? Unfortunately, the hope that the discovery of the system would provide ways of preventing the pulmonary complications of paraquat intoxication, by blocking its cellular uptake, has not materialised, partly because of the very narrow toxicokinetic time frame in which uptake inhibitors would have to be given. ${ }^{22} 23$ Nevertheless, the existence of the uptake system can probably be used to assess the function of the alveolar epithelium. So far this has only been done in vitro and ex vivo in animal models of alveolar injury. ${ }^{911124}$ It would be conceivable, however, to take advantage of this metabolic function also in vivo-for example, by administering a non-toxic $\gamma \overrightarrow{\vec{\omega}}$ emitting substrate of the uptake system in 0 order to evaluate the alveolar epithelium non- $\vec{x}$ invasively. In the present study, when poss- $\underset{\infty}{\infty}$ ible, we have also incubated tumour tissue with putrescine and found no evidence for uptake in either squamous cell carcinomas or $\overrightarrow{\mathrm{N}}$ adenocarcinomas (unpublished observations). O However, because some lung tumours, ? notably bronchioloalveolar carcinomas, ${ }^{25}$ have $\overrightarrow{ }$ phenotypic features of type II cells or Clara cells, it would be interesting to study the uptake of polyamines in such tumours. Similarly, it would be interesting to study conditions of non-malignant type II cell pro- $\vec{\oplus}$ liferation and hyperplasia. Another potential use of the uptake system lies in the targeting of drugs to the alveolar epithelium, by design- $\sum^{2}$ ing them to be transported via the polyamine/ cystamine uptake system. Finally, we hope that further studies of these processes may $\stackrel{\mathbb{\perp}}{\propto}$ contribute to the elucidation of the mecha- $\overline{\vec{\beta}}$ nisms of growth, proliferation, and differentiation in the lung, on the one hand, and $\vec{F}$ those of defence against oxidation on the other.

We thank Professor G Deneffe, the pathologists, and technical 0 staff for their cooperation with the sampling and processing of the tissue, and J Erna, F Rochette, and S Preston for their practical help. We are grateful to Carl Zeiss, Oberkochen, Germany, for the use of the EM 902A electron microscope.

This research was sponsored under project OT89/24 KU Leuven. CPL Lewis (who died 12 May 1993) was a recipient of a European Science Foundation fellowship in toxicology.

1 Jänne J, Alhonen L, Leinonen P. Polyamines: from molec- $\mathrm{C}$ ular biology to clinical applications. Ann Med 1991;23: O 241-59.

2 Pegg AE. Polyamine metabolism and its importance in neoplastic growth and as a target for chemotherapy. Cancer Res 1988;48:759-74.

3 Rose MS, Smith LL, Wyatt I. Evidence for energydependent accumulation of paraquat into rat lung.
Nature 1974;252:314-5.

4 Smith LL. The identification of an accumulation system $D$ for diamines and polyamines into the lung and its rele- $\overparen{\mathbb{D}}$ vance to paraquat toxicity. Arch Toxicol 1982;Suppl. 5ance to paraquat toxicity. Arch Toxicol 1982;Suppl. 5:1-14.

5 Rannels DE, Pegg AE, Clark RS, Addison JL. Interaction of paraquat and amine uptake by rat lungs perfused in $\delta$ situ. Am f Physiol 1985;249:E506-13.

6 Lewis CPL, Haschek WM, Wyatt I, Cohen GM, Smith $\mathrm{LL}$. The accumulation of cystamine and its metabolism to taurine in rat lung slices. Biochem Pharmacol 1989; to taurine

7 Smith LL, Wyatt I, Cohen GM. The accumulation of diamines and polyamines into rat lung slices. Biochem Pharmacol 1982;31:3029-33. 
8 Brooke-Taylor S, Smith LL, Cohen GM. The accumulation of polyamines and paraquat by human peripheral lung. Biochem Pharmacol 1983;32:717-20.

9 Nemery B, Smith LL, Aldridge WN. Putrescine and 5hydroxytryptamine accumulation in rat lung slices: cellular localization and responses to cell-specific lung injury. Toxicol Appl Pharmacol 1987;91:107-20.

10 Wyatt I, Soames AR, Clay MF, Smith LL. The accumulation and localisation of putrescine, spermidine, spermine and paraquat in the rat lung. In vitro and in vivo studies. Biochem Pharmacol 1988;37:1909-18.

11 Dinsdale D, Preston SG, Nemery B. Effects of injury on $\left[{ }^{3} \mathrm{H}\right]$ putrescine uptake by types I and II cells in rat lung slices. Exp Mol Pathol 1991;54:218-29.

12 Kameji R, Rannels SR, Pegg AE, Rannels DE. Spermidine uptake by type II pulmonary epithelial cells in primary culture. Am $\mathcal{f}$ Physiol 1989;256:C160-7.

13 Lewis CPL, Demedts M, Nemery B. Indices of oxidative stress in hamster lung following exposure to cobalt(II) ions: in vivo and in vitro studies. Am $\mathcal{F}$ Respir Cell Mol Biol 1991;5:163-9.

14 Fisher AB, Reicherter J. Pentose pathway of glucose metabolism in isolated granular pneumocytes. Metabolic regulation and stimulation by paraquat. Biochem Pharmacol 1984;33:1349-53.

15 Cardenas A, Nemery B. Effects of pneumotoxic trialkylphosphorothioates on the pentose phosphate pathway in rat lung slices. Toxicol Lett 1991;56:339-48.
16 Engel PC. Outline studies in biology: enzyme kinetics, steadystate approach. London: Chapman and Hall, 1981.

17 Eisenthal R, Cornish-Bowden A. The direct linear plot. A new graphical procedure for estimating enzyme kinetic parameters. Biochem f 1974;139:715-20.

18 Williamson DF, Parker RA, Kendrick JS. The box plot: a simple visual method to interpret data. Ann Intern Med 1989;110:916-21.

19 Nemery B, Dinsdale D, Verschoyle RD. Detecting and evaluating chemical-induced lung damage in experimental animals. Bull Eur Physiopathol Respir 1987;23:501-28.

20 Smith LL, Wyatt I. The accumulation of putrescine into slices of rat lung and brain and its relationship to the accumulation of paraquat. Biochem Pharmacol 1981;30: 1053-8.

21 Rao SB, Mehendale HM. Passive sequestration of putrescine, spermidine and spermine by rat lungs. Biochim Biophys Acta 1988;966:22-9.

22 Smith LL. Mechanism of paraquat toxicity in lung and its relevance to treatment. Hum Toxicol 1987;6:31-6.

23 Davies DS. Paraquat poisoning: the rationale for curren treatment regimes. Hum Toxicol 1987;6:37-40.

24 Smith LL, Lewis CPL, Wyatt I, Cohen GM. The importance of epithelial uptake systems in lung toxicity. Environ Health Perspect 1990;85:25-30.

25 Clayton F. Bronchioloalveolar carcinomas. Cell types, patterns of growth, and prognostic correlates. Cancer 1986;57:1555-64. 